\title{
INHIBITION OF SEROTONIN-MEDIATED CARDIOVASCULAR REFLEXES BY CIMETIDINE IN THE RABBIT
}

\author{
Roger C. WigGins ${ }^{1}$ and ANNA M. CAMPBell ${ }^{2}$ \\ ${ }^{1}$ Department of Internal Medicine, University of Michigan Medical School, Ann Arbor, MI 48109 and \\ ${ }^{2}$ Research Institute of Scripps Clinic, La Jolla, CA 92037, U.S.A.
}

(Received 1 October 1982)

Abstract-1. Cimetidine inhibits serotonin-mediated cardiovascular autonomic chemoreflexes in the rabbit.

\section{INTRODUCTION}

Cimetidine has been used as a specific $\mathrm{H}_{2}$ histamine antagonist (Douglas, 1980). In this study the ability of cimetidine to inhibit serotonin-mediated autonomic reflexes in the rabbit is described.

\section{METHODS}

Rabbits (2.5-3 kg New Zealand white) were fasted for $36 \mathrm{hr}$ prior to study. Anesthetic (sodium pentobarbitone,

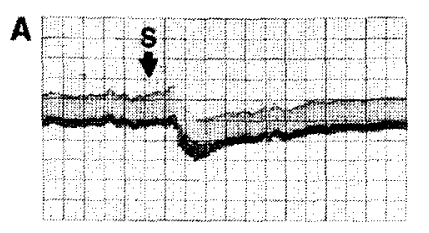

$15 \mathrm{mg} / \mathrm{kg}$ ) was injected slowly via the marginal ear vein until anesthesia was induced. Rabbits were placed supine on boards and held in position by loops of cord to the limbs. Hair was clipped from the femoral region, and femoral arterial and venous catheters were placed under local anesthetic. The catheters (Intramedic PE 50 polyethylene tubing) were introduced to the level of the diaphragm. Arterial pressure was recorded using a Statham pressure transducer (P73B) attached to a Statham SP 1400 Blood Pressure Monitor.

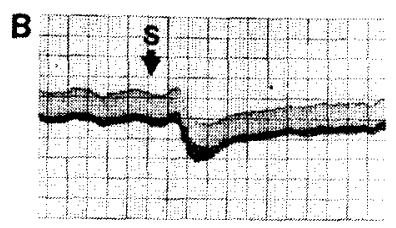

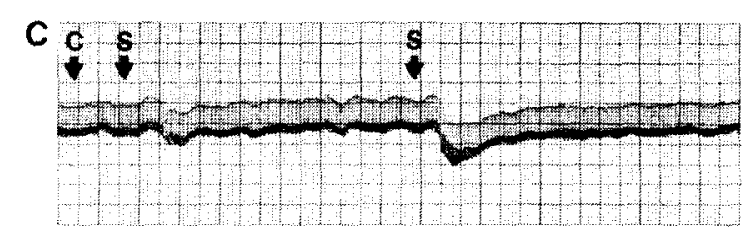
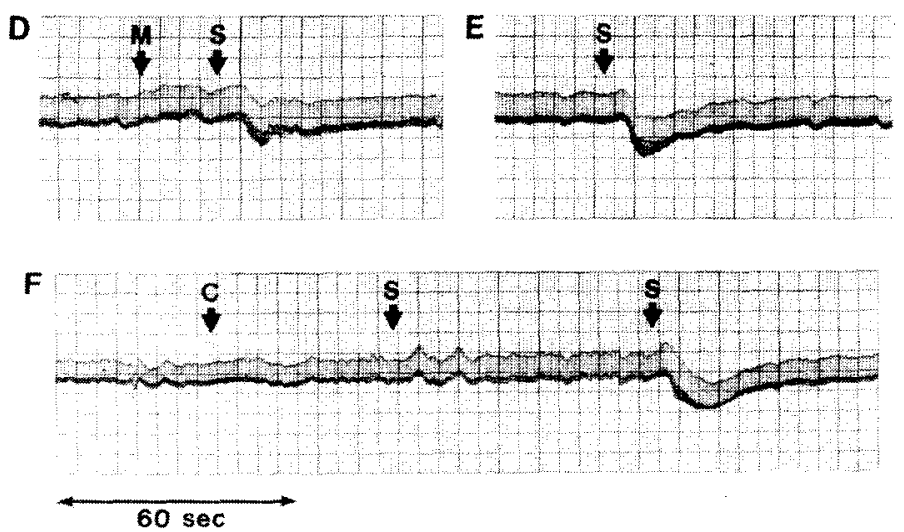

Fig. 1. Serotonin ( $22 \mu \mathrm{g}$ serotonin base injected i.v.) reproducibly caused a small rise in systemic arterial pressure followed by a $30 \%$ fall in arterial pressure accompanied by bradycardia (A and B). Administration of cimetidine ( $3 \mathrm{mg}$, i.v.) inhibited the hypotension and bradycardia induced by serotonin ( $22 \mu \mathrm{g}$, i.v.) (C). However, $1 \mathrm{~min}$ later the rabbit was again fully responsive to the serotonin injection ( $22 \mu \mathrm{g}$, i.v.). Methysergide ( $3 \mathrm{mg}$ base) also partially abolished the serotonin-mediated hypotension and bradycardia (D). This inhibition had disappeared within $2 \mathrm{~min}$ (E). Administration of cimetidine $(5 \mathrm{mg} / \mathrm{kg})$ totally abolished the serotonin-induced hypotension and bradycardia $(F)$. This inhibition had almost disappeared within $1 \mathrm{~min}$. 


\section{Drugs}

Serotonin (Serotonin creatine sulfate, Sigma Chemical $\mathrm{Co}$., St Louis, MO) was dissolved in sterile normal saline. Methysergide maleate was kindly provided by Ms K. D. Roskaz of Sandoz Inc., East Hanover, NJ. It was dissolved in sterile normal saline. Cimetidine $\mathrm{HCl}$ (Tagamet) was purchased from Smith, Kline \& French Laboratories, Philadelphia, PA and was diluted in normal saline prior to injection. All drugs were injected as a bolus injection.

\section{RESULTS}

$\Lambda$ bolus injection of $22 \mu \mathrm{g}$ serotonin base into a catheter placed in the midabdominal inferior vena cava of a rabbit reproducibly induced a $30 \%$ fall in systemic arterial pressure accompanied by transient bradycardia (Fig. 1). Intraarterial injection of the same amount of serotonin induced a transient rise in systemic arterial pressure (data not shown).

The hypotension and bradycardia could be inhibited completely by cimetidine $(5 \mathrm{mg} / \mathrm{kg})$ given as an intravenous bolus within $1 \mathrm{~min}$ before the Serotonin response to serotonin. Cimetidine appeared to be as effective as methysergide at inhibiting serotonininduced hypotension (Fig. 1).

The same result was obtained in five rabbits.

Administration of a large dose of cimetidine $(100 \mathrm{mg} / \mathrm{kg}$ given i.v. over $20 \mathrm{~min})$ resulted in inhibition of serotonin-induced reflexes for at least $1 \mathrm{hr}$ (data not shown).

\section{DISCUSSION}

The hypotension and bradycardia induced by intravenous serotonin administration in the rabbit is caused by autonomic reflexes (Erspamer, 1966). Sero- tonin receptors are present in the lung, coronary artery bed and carotid sinus (Dawson \& Comroe, 1954). Stimulation of these receptors causes reflex bradycardia, hypotension and apnea. These reflexes can be prevented by cutting the vagus, depressor and carotid sinus nerves in the rabbit and can be inhibited by administration of methysergide (Erspamar, 1966; Douglas, 1980).

Cimetidine has been developed and is used clinically as a specific $\mathrm{H}_{2}$ histamine antagonist (Douglas, 1980). The data presented here show that cimetidine also blocks serotonin-induced autonomic reflexes in the rabbit. This effect may be caused by competition between serotonin and cimetidine for those receptors since the blocking effect of a relatively small amount of cimetidine was short-lived and similar to that of the known serotonin antagonist methysergide.

Cimetidine is proving to have a wide range of clinical effects. It is conceivable that some of these effects are at least partially due to its ability to antagonize serotonin.

\section{REFERENCES}

Dawson G. S. \& Comroe J. H. (1954) Chemoreflexes from the heart and lungs. Physiol, Rev. 34, 167-201.

Douglas W. W. (1980) Autocoids. In The Pharmacological Basis of Therapeutics (Edited by Goodman A. G., GoodMAN L. S. \& CRILMAN A.), pp. 608-667. Macmillan, New York.

ERSPamer V. (1966) (Ed.) Peripheral physiological and pharmacological actions of indole alkylamines. In Handbook of Experimental Pharmacology XIX. 5-Hydroxytryptamine and Related Indole Alkylamines, pp. 245-351. Springer-Verlag. New York. 